旋光性：物貿 $0.0437 \mathrm{~g}$ を水汇溶解して $10 \mathrm{cc}$ となす。 $l=1 \mathrm{dm} ; \alpha=+0.20^{\circ}$ 因つて $\left.[\alpha]\right]_{\mathrm{D}}^{18}=+$ $45.77^{\circ} \mathrm{O}$

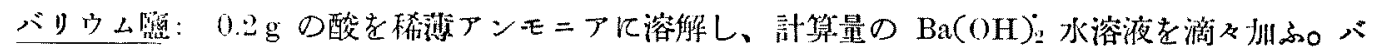

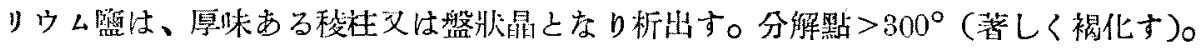

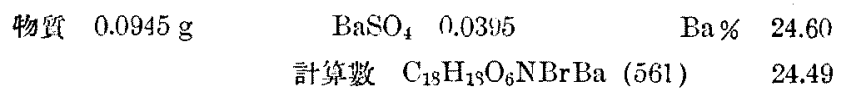

\title{
1・プローム・シノメニン
}

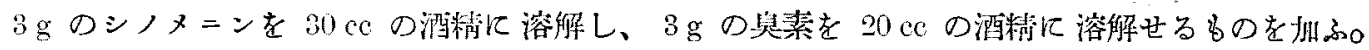

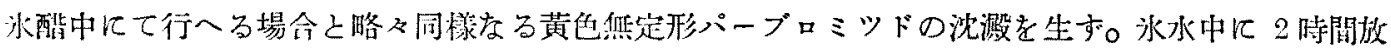

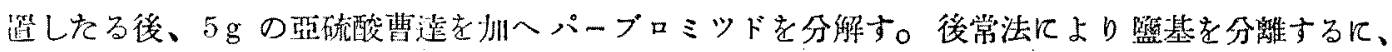

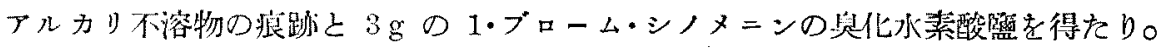

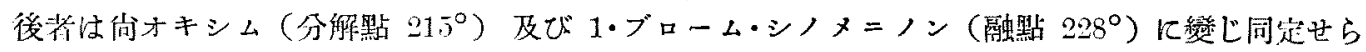
れた 。

(於北里研究所)

\section{苛性アルカリのアルコール溶液に依るエーテルの 分解に就て（第一報）}

(昭和七年五月三日受領

昭和七年七月州五日印刷)

平尾子光吉

アルカリ揢融にてフェノールェーテルが分解してフェノール化合物を生ずるは從來交缺に乏しから ず、本邦にて b最近小松、时中兩比”は Oxycinnamic acid, Oxybenzoic acidのメチルェーテル、ヂ

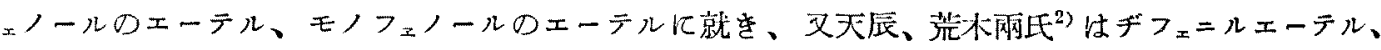
ヂンジルェーテル等が分解してフェノール化合物を生ずる研究あり。アルカリ水溶液にても分解起

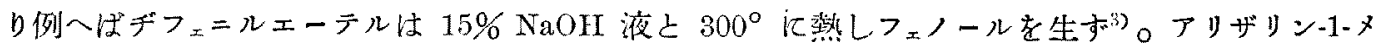

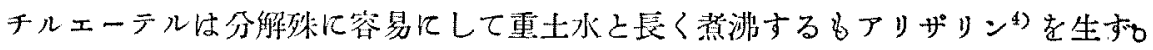

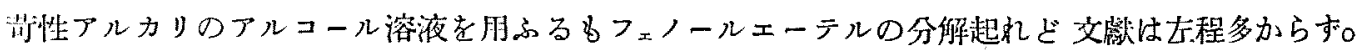

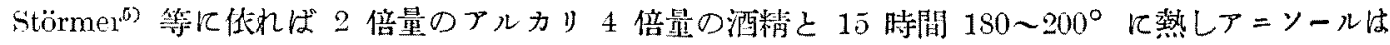
$11.6 \% 、 フ_{x}$ ホトールは $20 \%$ のフェノルを生す。

核に於ける置㒜基が酸性の物なる時はェーテルの分解を容易にし例へばトリニトロアンソールは 酒精刑性加里溶液之熱するも分解 OH と交る。

1) 本誌、 51 (1930), 138.2 2) 本誌。 $52(1931), 484 . \quad$ 3) Meyer, Berzelius: Ber., 47 (1914), 3158 . 4) Perkin: J. Chem. Soc., 91 (1907), $2069 . \quad 5)$ Störmer, Kalert: Ber., 34 (1901), 1812; 36 (1903), 5995. 6) Cahours: Ann., 69 (1849), 237; Salkowski: Ann.. 174 (1874), ¿59; Blom: Helv., 4 (1921) 10. 7) Liebermann: Ber., 19 (1886), 2277. 
多價フェノールのェーテルは酒精つルカリ溶液にて上り容易に分解行はれい一般にアルキル基一 倜除去せらる。ヴェラツロールは孟力下に $200^{\circ}$ に處理しグァヤコールを生ず ${ }^{22}$ 。 E. P. $317347^{33} の$ 一部の中ルメチルオイダノール、メチルイソオイゲノール、3:4-Diethoxy-1-propenylbenzene は活 性加里の酒精溶液之熱すれば一部のアルキル除去せらるとせり、ピロガロールトリアルキルエーテ ルはピロガロール-1:3-ヂアルキルェーテルをとなる。シブオールテトラメチルェーテルは酒粘詩性 加里溶液にて、Gallic acid のトリメチルェーテルを生ぜ り゙。二價フェノールのェーテルに Grignard's reagent（約 $1 \mathrm{~g}$ 分子量)を作用するにアルキル基同一なれば收量は異るも二方向几分解起り、

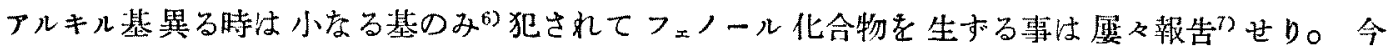
Grignard's reagent に代ふるに势性つルカリの酒精溶液を朋ふれば如何なる結果を得るやは頗る興 味ある閣題なれば此硐労に着手し其一部を報告す。

本研究の結果に位れば二つのアルキル基が同一なりとも罢るとる二方向て分解起り、其生成フ ノール泿合物の性質とGrignard's reagent の作用に你るフェノールとの性質を比較し後者の場合小 なるアルキル基のみが分解せらる」證を谷及確むる事之なれるは豫想外の收穕なりを。

荊性加里( 久は武性曹淕)の木精溶液之熱するに<smiles>C=CCc1ccc(OC)c(OC)c1</smiles>

Methyleugenol

(Methylisoeugenol)

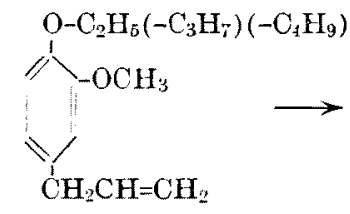

$\left(\mathrm{CH}=\mathrm{CH} \cdot \mathrm{CH}_{3}\right)$

Eugenol ether

(Isoeugenol ether)

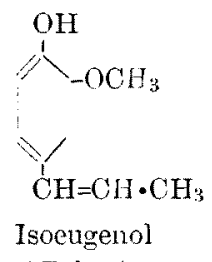

（量少し)

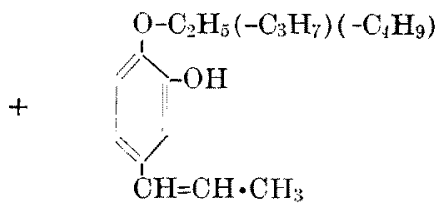

（显多し)

インカヴィベトールのェーテルに於てb、記之同样の關係にあり。

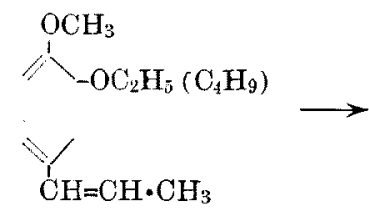

Isochavibetol ether

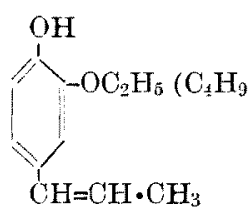

（量多し）

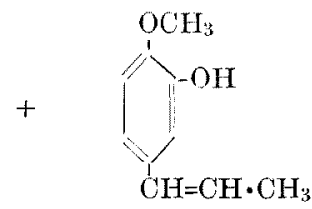

Isochavibetol

(㻎少し)

1) Houben-Weyl: 'Die Methoden d. Arg. Chem.' II Auf. III 137. 2) D. R. P. 78910, 92651 ; Bouveault: Bull. Soc. Chim., III. 19 (1898), 75. 3) Graesser-Monsanto Chemical Works (1928). 4）D.R.P. 162658. 5) 小松、倉田：本誌、51 (1930)，138．6）フルキルにあらざるすのに例外あり。 7) 本誌、 $53(1932), 488$. 
フルキルとベンチルとが共存するェーテルに Grignard's reagent を作用せしむるにペンチル基犯 さる゙、苛性ア゙ルリのアルコール溶液を用ふるもベンチル基に於て分解せるフェノール化合體のみ 碓證し得をるが、若しベンチル基殘りナルキル基に於て分解せる物を生ぜるとる其量は少かるへく 此點は倍後日に褧る。<smiles>C=CCc1ccc(OCC)c(OCC)c1</smiles>

$\left(\mathrm{CH}=\mathrm{CH} \cdot \mathrm{CH}_{3}\right)$

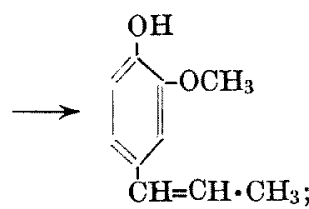

Isoeugenol

Engenol or Isoeugenol benzyl ether<smiles>CC=Cc1ccc(OC)c(OCc2ccccc2)c1</smiles>

Isochavibetol benzyl ether

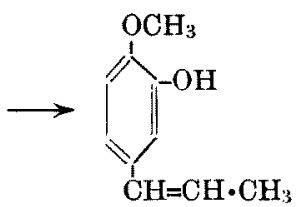

Isochavibetol

3:4-Diethoxy-1-propenylbenzene に於ては次の如く分解す。<smiles>CC=Cc1ccc(OCC)c(OCC)c1</smiles><smiles>CC=Cc1ccc(O)c(OCC)c1</smiles><smiles>CC=Cc1ccc(OCC)c(O)c1</smiles>

\section{實驗之部}

1. メチルオイゲノール （イ）オイゲノールを $\mathrm{KOH}$ と $\left(\mathrm{CH}_{3}\right)_{2} \mathrm{SO}_{4}$ にて常法に位りメチル 北して得。

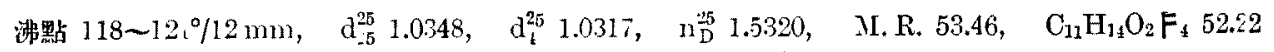

（ロ）メチルオイゲノール $4.1 \mathrm{~g}$ を $\mathrm{KOH}$ (局法) $4 \mathrm{~g}$ 、问販 $99 \%$ メタール $20 \mathrm{~g}$ の溶液に扠 へオートクーレブ中 180 〜 $200^{\circ}$ の油浴に 2.5 時間熱し、放冷後水を加へエーテルにて抽出し中性 物質を取る、斯くしてメチルインオイゲノール $9.7 \mathrm{~g}$ を得たり。

$$
\text { 沸點 } 14 \sim 136^{\circ} / 11 \mathrm{~mm}, \quad \quad \mathrm{n} \frac{0}{\mathrm{n}} \quad 1.563
$$

份不純なるも二尖物融點 100〜1010 を造りて證す（混融）。

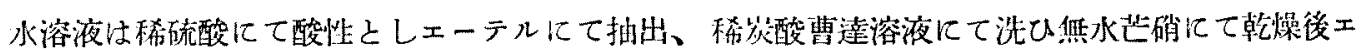

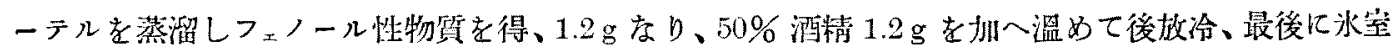

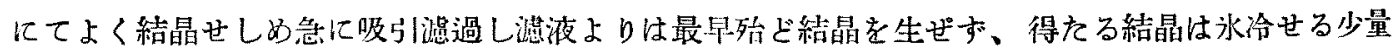

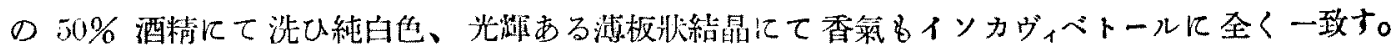
$0.3 \mathrm{~g}$ あ。融啙 $92^{\circ}$ 、混融してインカヴィベトールなるを確登す。母液は $\mathrm{KOH} 0.33 \mathrm{~g} 、 \mathrm{C}_{6} \mathrm{H}_{5} \mathrm{COCl}$ $0.7 \mathrm{~g}$ を加八水冷の下にベンゾェートを造る。90\% 酒精にて一包再結晶するのみにて融點 102〜

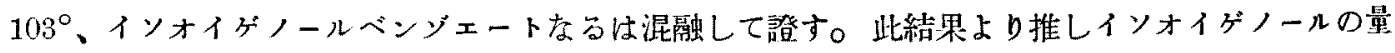
インカヴィヘトールの量よりも多し。

（ハ） $\mathrm{KOH}$ を虽量の $\mathrm{NaOH}$ にて琶换し、义は $\mathrm{KOH}, \mathrm{NaOH}$ の同量混合物を用ひて研究する に前記と㱠ど同棣の結果を得たり、只 $\mathrm{NaOH}$ が KOH に比し溶解度小なるを不便とす。

1) 本誌、 53 (19:32), 488. 


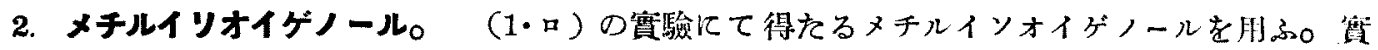

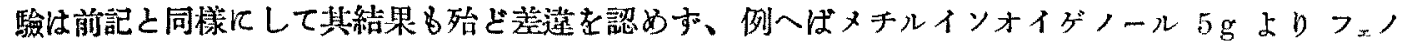

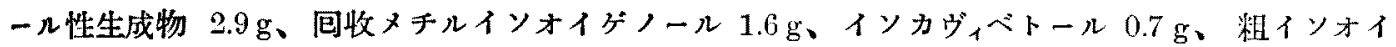
ゲノール2.2 $\mathrm{g}$ な

3. イリオイゲノール及イリカヴィントトールのアセテート及ベンゾェートの融點圖。インオイ ダノール及インカヴィベトールの混合物は稀酒棹、稀木精、其他 $2 \sim 3$ 有機溶劑にて處理しインカ ヴィベールは整めて容易に分離せられインオイら゙ノールは僅少量にインカヴィベトールを含有する

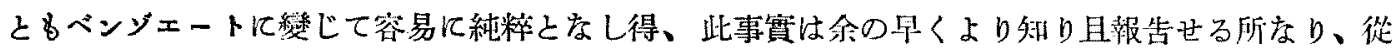
て融點圖の如ををつくりて混合割合を沃する如を必要は認めす、且インカヴィベトールは混合物の場

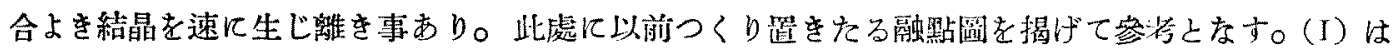
混合物のア七テート、(II) はベンゾェートの融點 圖なり。融點泪定法は Rast の分子量测定法と操 作、注意を同しくくして行ひ良を結果を得たり。

(I)

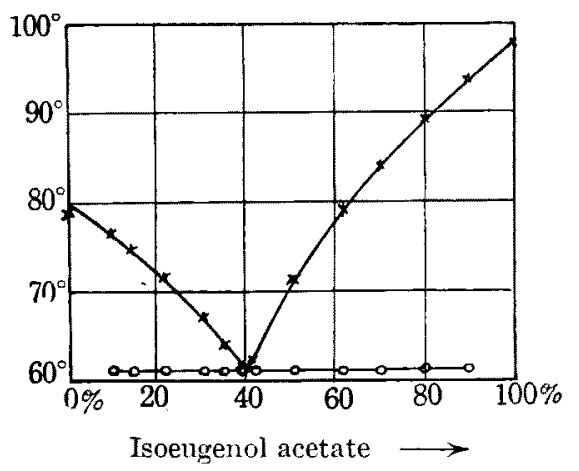

Isoeugenol acetate $\mathrm{g}$

$\begin{array}{cc}- & - \\ 0.0693 & 0.0075 \\ 0.0535 & 0.0107 \\ 0.0380 & 0.0103 \\ 0.0227 & 0.0101 \\ 0.0589 & 0.0349 \\ 0.0129 & 0.0084 \\ 0.0301 & 0.0208 \\ 0.0118 & 0.0125 \\ 0.0112 & 0.0177 \\ 0.0123 & 0.0288 \\ 0.0074 & 0.0300 \\ 0.0063 & 0.0573\end{array}$

Isoeugenol acetate \%

100.00

90.23

83.33

78.68

69.21

62.79

60.56

59.14

48.56

39.02

30.00

20.00

10.00

0.00
(II)

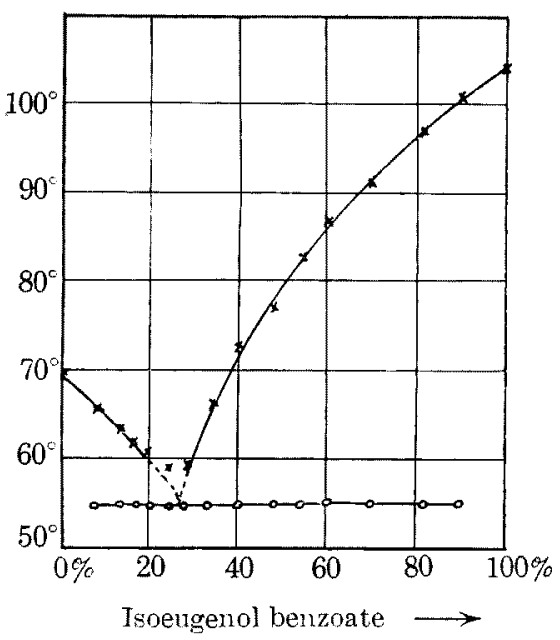

Isochavibetol acetate \%

溊化點

㼛點

$\begin{array}{rll}0.00 & - & 79 \sim 80^{\circ} \\ 9.77 & 60.8^{\circ} & 77.0^{\circ} \\ 16.67 & 60.8^{\circ} & 74.8^{\circ} \\ 21.32 & 60.8^{\circ} & 72.1^{\circ} \\ 30.79 & 60.8^{\circ} & 67^{\circ} \\ 37.21 & 60.6^{\circ} & 64.4^{\circ} \\ 39.44 & 60.8^{\circ} & 62.4^{\circ} \\ 40.86 & 60.8^{\circ} & 62.5^{\circ} \\ 51.44 & 60.8^{\circ} & 72^{\circ} \\ 60.98 & 60.7^{\circ} & 79.2^{\circ} \\ 70.00 & 60.8^{\circ} & 84^{\circ} \\ 80.00 & 61.4^{\circ} & 84.5^{\circ} \\ 90.00 & 61.5^{\circ} & 94^{\circ} \\ 100.00 & - & 98^{\circ}\end{array}$




\begin{tabular}{|c|c|c|c|c|c|}
\hline $\begin{array}{l}\text { Isoengenol } \\
\text { benzoate g }\end{array}$ & $\begin{array}{c}\text { Isochavibetol } \\
\text { benzoate } g\end{array}$ & $\begin{array}{l}\text { Isoeugenol } \\
\text { benzoate } \%\end{array}$ & $\begin{array}{l}\text { Isochavibetol } \\
\text { benzoate } \%\end{array}$ & 潤化點 & 愿點 \\
\hline- & - & 0.00 & 100.00 & - & $69 \sim 70^{\circ}$ \\
\hline 0.0104 & 0.0911 & 8.22 & 91.78 & $54.5^{\circ}$ & $65.5^{\circ}$ \\
\hline 0.0140 & 0.0874 & 13.81 & 86.19 & $55^{\circ}$ & $63.5^{\circ}$ \\
\hline 0.0104 & 0.0500 & 17.22 & 82.78 & $54.5^{\circ}$ & $62^{\circ}$ \\
\hline 0.0107 & 0.0418 & 20.38 & 79.62 & $55^{\circ}$ & $61^{\circ}$ \\
\hline 0.0098 & 0.0329 & 2295 & 77.05 & $54.5^{\circ}$ & $60.5^{\circ}$ \\
\hline 0.0105 & 0.0318 & 24.82 & 75.18 & $55^{\circ}$ & $59^{\circ}$ \\
\hline 0.0149 & 0.0392 & 27.54 & 72.46 & $54.5^{\circ}$ & $59.5^{\circ}$ \\
\hline 0.0100 & 0.0212 & 34.27 & 65.73 & $54.5^{\circ}$ & $660^{\circ}$ \\
\hline 0.0162 & 0.0238 & 40.35 & 59.65 & $54.5^{\circ}$ & $73.25^{\circ}$ \\
\hline 0.0175 & 0.0190 & 47.94 & 52.06 & $55^{\circ}$ & $77^{\circ}$ \\
\hline 0.0319 & 0.0271 & 53.90 & 46.10 & $54.5^{\circ}$ & $83.25^{\circ}$ \\
\hline 0.0167 & 0.0110 & 60.29 & 39.71 & $54.5^{\circ}$ & $86.5^{\circ}$ \\
\hline 0.0310 & 0.0131 & 69.82 & 30.18 & $55^{\circ}$ & $91.25^{\circ}$ \\
\hline 0.0424 & 0.0101 & 80.75 & 19.24 & $56^{\circ}$ & $97^{\circ}$ \\
\hline 0.0767 & $0.008 \overline{5}$ & 90.02 & 9.98 & $55.5^{\circ}$ & $101.1^{\circ}$ \\
\hline- & - & 100.00 & 0 & - & $103 \sim 104^{\circ}$ \\
\hline
\end{tabular}

\section{4. オイゲノールエチルエーテル}

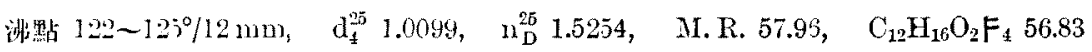
なる恒数を何するオイゲノールェチルェーテル $7.1 \mathrm{~g}, \mathrm{KOH}$ (局法) $7.2 \mathrm{~g}$ 占販 $99 \%$ メタノール

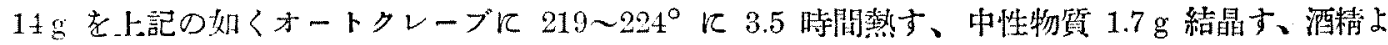

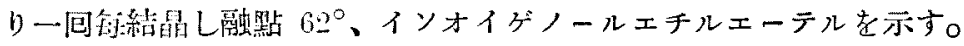

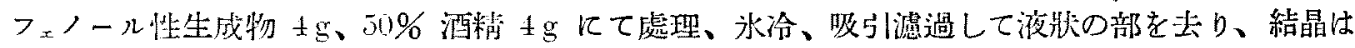

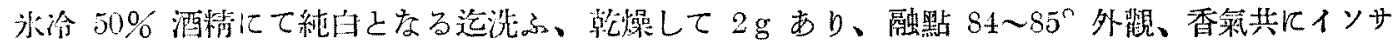
フロオイゲノール上ー致す。

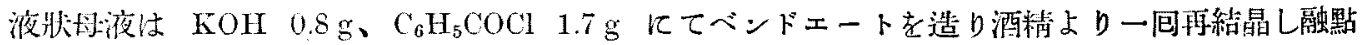

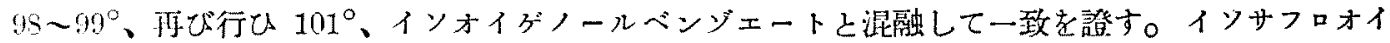
ゲノールの量イソオイங゙ノールよりる多旁事推定せらる。

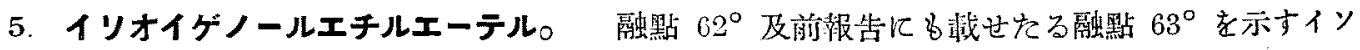
オイダノールエチルェーテル $1.7 \mathrm{~g} 、 \mathrm{KOH} 2.5 \mathrm{~g}$ 、無水朴精 $5 \mathrm{~g}$ の溶液を常法の如く $201 \sim 210^{\circ} \pi$

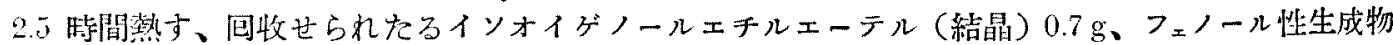
0.7 、 $50 \%$ 酒精を用ひ常法の如く分ちてインサフロオイがノール融點 $85^{\circ} 0.3 \mathrm{~g}$ 他几台不純の物あ り、丹液よりベンゾェートを造り酒精に溶解放谓し、自然蒸發せしめ結晶し難かりしを以てインオ

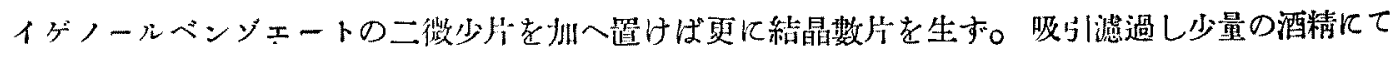
粗液を沙ひ融點 100〜102。イソオイダノールベンゾェートを示す。

\section{6. オイゲノール n-プロピルエーテル。}

沸點 $122.5^{\circ} / 10 \mathrm{~mm} \quad \mathrm{~d}_{25}^{25} 0.9923, \quad \mathrm{~d}_{4}^{55} 0.9904, \quad \mathrm{n}_{\mathrm{D}}^{25}$ 1.5182, M. R. 63.05, $\quad \mathrm{C}_{13} \mathrm{H}_{13} \mathrm{O}_{2} \mathrm{~F}_{4} 61.43$ 


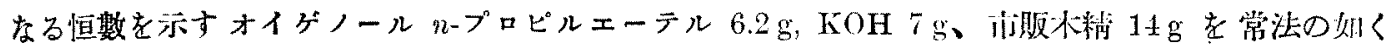
$219 \sim 220^{\circ}$ に 3 跱間熹す。

回收せられたる中性物 $4.9 \mathrm{~g}$ 、融點 $47.5^{\circ}$ インオイダノールn-ブロビルェーテルなり。

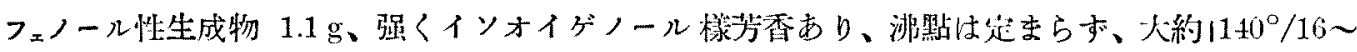

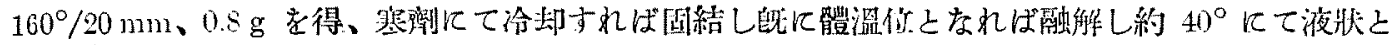
化す。舌に觸れば始ど甘味のみ、60\% 酒精にて再絬晶し融點 $43 \sim 44^{\circ}, 0.4 \mathrm{~g}$ を得、3-Hydroxy-4-

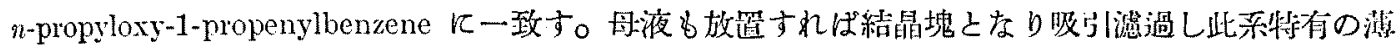
板狀白色結晶を得、斯くて絬晶を生ぜざるに到れる黄色油狀物を含める同液は KOH $0.15 \mathrm{~g}$ ， $\mathrm{C}_{6} \mathrm{H}_{5} \mathrm{COCl} 0.4 \mathrm{~g}$ にてベンゾェートとなし酒精に溶解放置すれば少量なれど見事なる結晶を生じ酒精

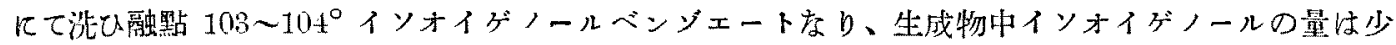
Lo

7. イリオイゲノール $n$-プロピルエーテル。 （イ）3-Hydroxy-4-n-propyloxy-1-propenylbenzene (融點 $\left.4 i^{\circ}\right)^{1)}\left(1.6 \mathrm{~g} \mathrm{KOH} 0.2 \mathrm{~g}\right.$ 、水少量、 $\mathrm{CH}_{3} \mathrm{I} 0.55 \mathrm{~g}$ 、朴精 $5 \mathrm{cc}$ を封管中湯浴飞 1.5 時間熟し水

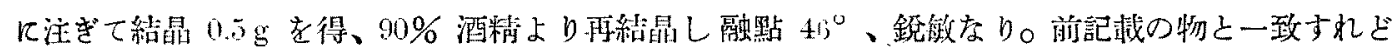
Beilstein の畫"

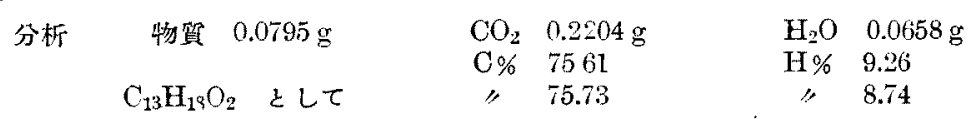

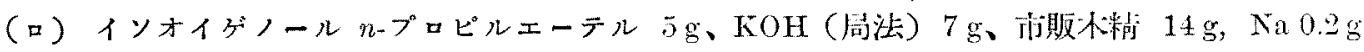

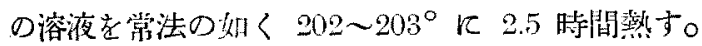

四收せるイソオイダノールn-プロピルェーテル $3.5 \mathrm{go}$

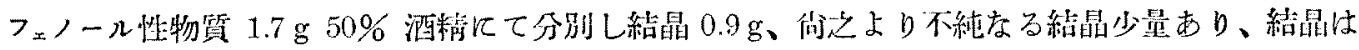

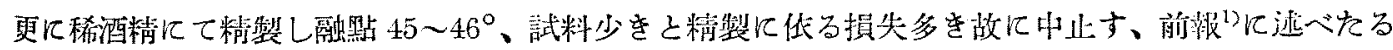
3-Hydroxy-4-n-propyloxybenzene たるは疑ひ無し。団液はベンジェートを造り酒精に溶解し生ずる 結晶は少量なり、融點 $101^{\circ}$ 。イソオイゲノールベンソェェートを示す。

8. オイゲノールペンチルエーテル。 (イ ) オイゲノール $8.2 \mathrm{~g}, \mathrm{KOH} 3.8 \mathrm{~g}, \mathrm{C}_{6} \mathrm{H}_{5} \mathrm{CH}_{2} \mathrm{Cl} 12.7 \mathrm{~g}$ 闫販木精 $20 \mathrm{~g}$ 老这流冷却器下に 1 時間湯浴上に者渄す。得をるべンチルェーテル $16 \mathrm{go}$

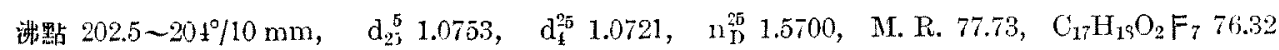

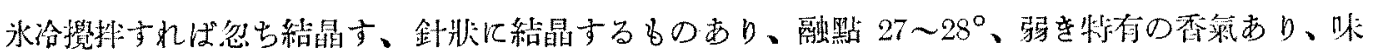

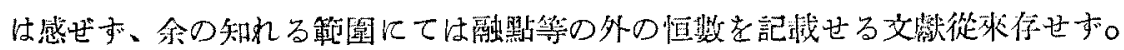

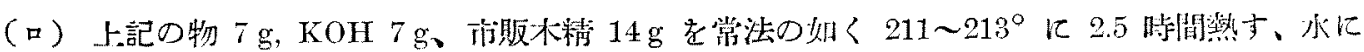
て稀程放冷すればインオイダノールベンチルェーテルの結晶析出し $5.8 \mathrm{~g}$ あり、融點 $49^{\circ}$ 。

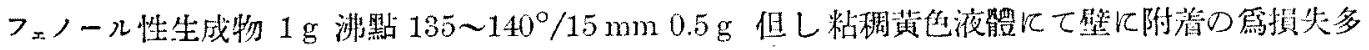
し、90\% 酒精 $3 \mathrm{~g}, \mathrm{KOH} 0.3 \mathrm{~g}, \mathrm{C}_{6} \mathrm{H}_{5} \mathrm{COCl} 0.6 \mathrm{~g}$ にて收量よく四狀ベンジェートを生じ $90 \%$ 酒䊑

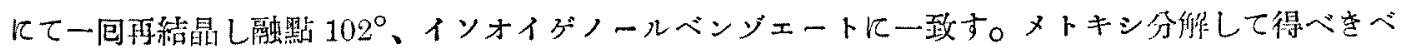
ンチルェーテルは生じ居らざる如く、若し生成せるとる微量なるべし。

9. イリオイゲノールベンチルエーテル。（イ）オイゲノールベンチルェーテル $19 \mathrm{~g} に \mathrm{KOH}$

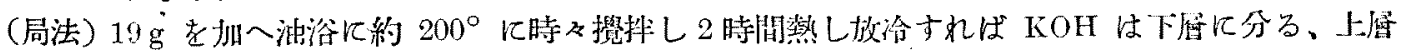

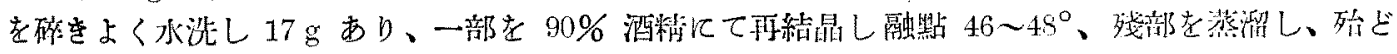
無也透明粘稑液體として溜出す。

1) 本誌、 $52(1931), 149,793.2$ 2) 'Organische Chemie' IV Auf. VI 957. 
沸點 $\quad 205 \% 111 \mathrm{~mm} \quad \quad{ }^{25} \mathrm{D} \quad 1.5956$

ピタノメーターに入れんとすればモ管の部より絬鼠す。impfenするも忽ち發熱全く紹晶す、味は 感ぜすั。

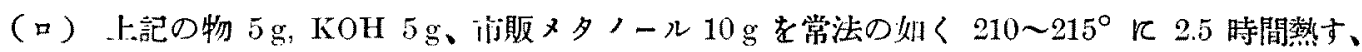
回收インオイダノールベンチルエーテル（絬晶） $3 \mathrm{~g} フ_{\mp}$ ノール生成物 $1 \mathrm{~g}: \mathrm{KOH} 0.4 \mathrm{~g}, \mathrm{C}_{6} \mathrm{H}_{5} \mathrm{COCl}$

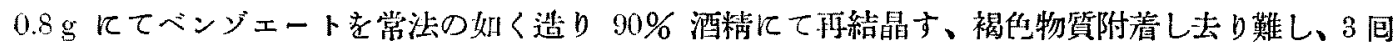
後に稍伹色となり融點 102〜103、イソオイがノールベンゾェートル一致す。

10. イリカヴィベトールエチルエーテル。＼cjkstart融點 $49^{\circ}$ の物 ${ }^{1)} 5.3 \mathrm{~g} 、 \mathrm{KOH} 5.3 \mathrm{~g}$ 、市販木精 $10.6 \mathrm{~g}$

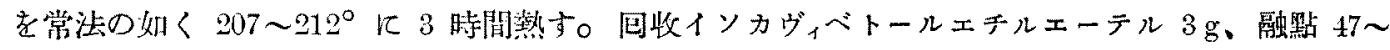

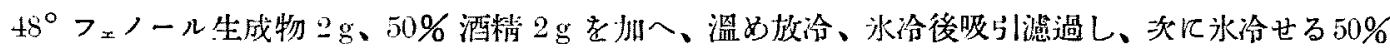

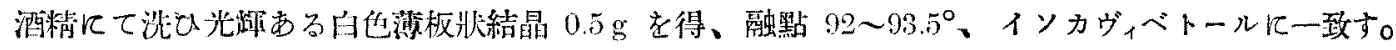
量は沃記の物より少し。

妇液に KOH $0.33 \mathrm{~g} 、 \mathrm{C}_{6} \mathrm{H}_{5} \mathrm{COCl} 0.7 \mathrm{~g}$ てでンンジェートを造り $90 \%$ 酒精にて再絬晶し融點約 $83^{\circ}$

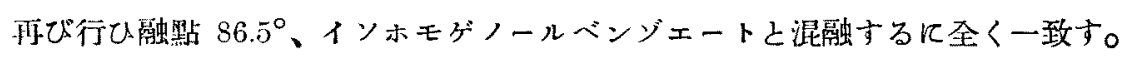

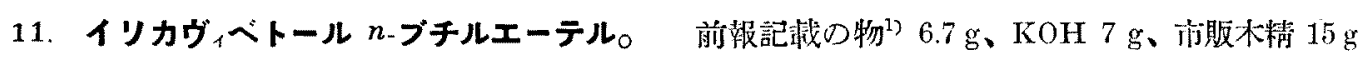
を管佧の如く 207〜2123に3 時间熱し、回收せられたる物 5.8 go

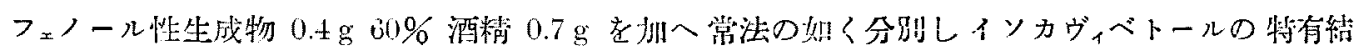
晶 $0.1 \mathrm{~g}$ 定得、融點 $92 \sim 93^{\circ}$ 。

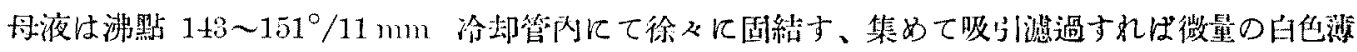

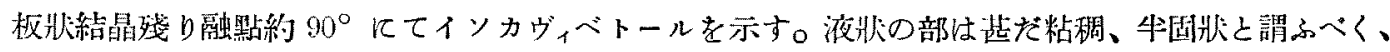
水冷すれば區絬し、香氣は弱けれどブチルアルコールを想起するが如をるのなり。酒精溶液は $\mathrm{FeCl}_{3}$

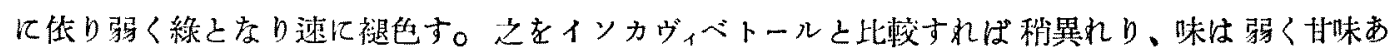

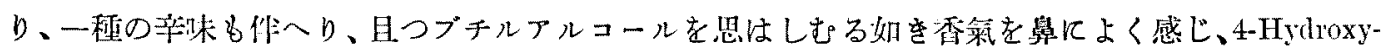
3-n-butyloxy-1-propenylbenzene ${ }^{1)}$ の特徽よよく一政し、之が生成し居るを示。り。

12. イソカヴベトールベンチルエーテル。 イソカヴィベトールベンチルェーテル 融點 88〜

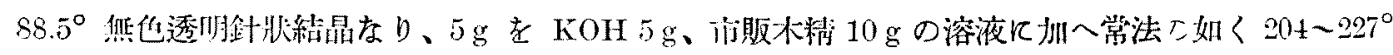

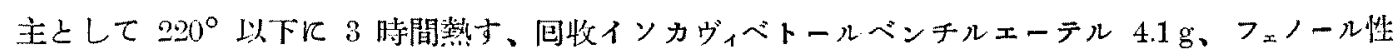

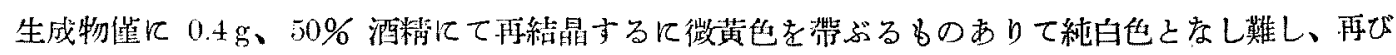

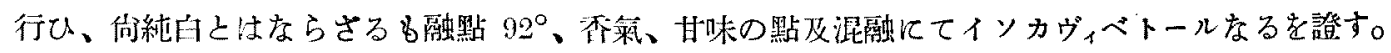

13. 3:4-ニエトキシ-1-プロペニルベンゼン。融點 $52^{\circ}$ の絬晶 $4.7 \mathrm{~g} 、 \mathrm{KOH} 5 \mathrm{~g}$ 、闺販不精 $10 \mathrm{~g}$ 、

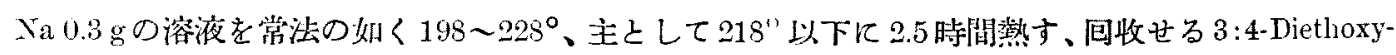
1-propenylbenzene $0.6 \mathrm{~g}>_{x}$ ノール性生成物は樹脂状物多く真空蒸溜精製すれ代收量激減し $50 \%$ 木

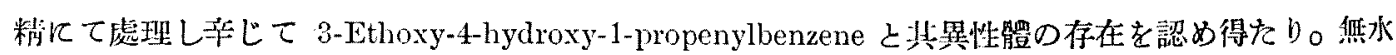

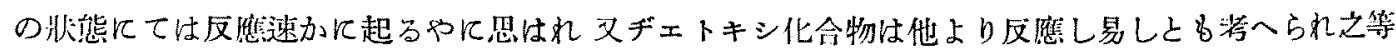
の點に就ては更に將來の研究に待たんとす。

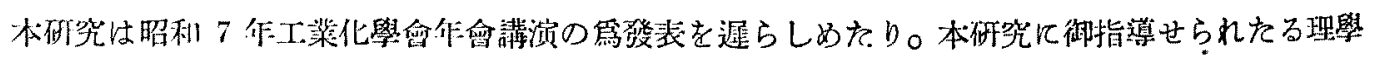

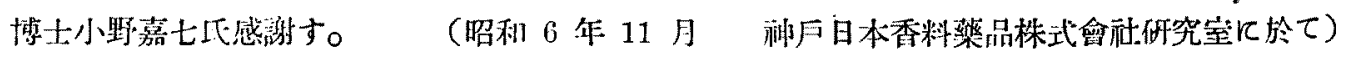

1) 本点、 52 (1931), 266. 